\title{
X-Linked Dominant Hypophosphatemic Rickets
}

National Cancer Institute

\section{Source}

National Cancer Institute. X-Linked Dominant Hypophosphatemic Rickets. NCI

Thesaurus. Code C85234.

An X-linked dominant disorder caused by mutations in the PHEX gene. It is characterized

by growth retardation, osteomalacia, hypophosphatemia, and defects in the renal

reabsorption of phosphorus. 